\title{
Análise do repertório dos receptores de linfócitos T expressos por células TCD4+ em camundongos FONX1CreERT2Dicerflox/flox
}

\section{Ana C. Medina Guillen*, José F. Teixeira da Silva Santos, Alessandro dos Santos Farias, Carolina Francelin}

\begin{abstract}
Resumo
O timo é um órgão linfoide primário essencial para o estabelecimento inicial do repertório de linfócitos $T$ maduros encontrados nos órgãos linfoides secundários. A geração do repertório de linfócitos T nos órgão linfóides secundários é dependente do processo de tolerância central aonde somente linfócitos cujo receptor não reconheça o antígeno próprio com alta afinidade são enviados para a periferia do sistema imune. Esse processo é mediado pelas células epiteliais tímicas que, por meio do fator de transcrição Aire, expressam antígenos próprios aos linfócitos em desenvolvimento. A função do Aire está relacionada a presença de microRNAs, mostrando que eles apresentam um papel no processo de seleção negativa. Assim, visando compreender melhor a participação dos microRNAs na geração de repertórios dos linfócitos, nesta trabalho avaliamos a expressão de diferentes recepetores de linfócitos T em células TCD4+ do baço de camundongos cuja expressão de Dicer pelas células epiteliais tímicas foi alterada.
\end{abstract}

Palavras-chave: Tolerância central, timo, microRNA, Dicer, linfócito $T$

\section{Introdução}

O timo é um órgão linfoide primário essencial para o estabelecimento inicial do repertório de linfócitos T maduros encontrados nos órgãos linfoides secundários ${ }^{1}$. Durante 0 desenvolvimento, os linfócitos $T$ sofrem processos de triagem, sendo o processo da seleção negativa, também conhecida como tolerância central, o mais importante. Ela ocorre nos linfócitos T duplo positivos que são induzidos a morte celular quando seu receptor (TCR) engaja com alta afinidade ao complexo peptídeoMHC próprio expresso pelas células epiteliais tímicas medulares (mTECs) ${ }^{1}$. A expressão ectópica de uma série de antígenos restritos ao tecido (tissue-restricted antigens TRAs) pelas células epiteliais medulares é controlada pelo modulador da transcrição Autoimmune regulator (Aire) ${ }^{2}$. Uma das moléculas essenciais para o procedimento da tolerância central é o microRNA (miRNA), que é um pequeno RNA, não-codificante cuja função é regulatória a nível pós-transcricional da expressão gênica. Esta molécula é produzida no núcleo da célula (primary-miRNA) onde suas sequências são clivadas em pequenos precursores de miRNA (pre-miRNA) que são exportados para o citoplasma e são clivados pela enzima Dicer formado o miRNA maduro ${ }^{3}$. A literatura demonstra que a expressão da proteína FOXN1 (Forkhead hox protein N1) é um regulador-chave para o desenvolvimento de mTECs. Desta forma, criamos camundongos FOXN1CREERT2Dicerfloxfllox, cujas células epiteliais tímicas tiveram Dicer depletado após a injeção de tamoxifeno. Sabendo que o processo de tolerância central é mediado pelas mTECs através da expressão de TRAs que são regulados por miRNAs; o foco desta pesquisa foi avaliar alterações no perfil de TCRs expressos por linfócitos TCD4+ em camundongos com e sem a expressão de Dicer no epitélio tímico.

\section{Resultados e Discussão}

Para nossas analises, geramos camundongos FONX1 ${ }^{\text {CreERT2}}$ Dicerfloxfllox. Os camundongos receberam tamoxifeno a partir do primeiro dia de vida até o dia anterior ao sacrifício para experimento seguindo protocolo padronizado em nosso laboratório. Após a eutanásia, o timo desses animais foi retirado para obtenção do dado de índice tímico e o baço foi processado rotineiramente para análise do repertório do TCR com 15 cadeias beta diferentes, por meio de citometria de fluxo com o painel CD3 (V500), CD4 (APC) e CD8 (PE). Os dados de citometria foram analisados no programa FlowJo e os gráficos e análises estatísticas foram realizados no programa GraphPad. Os resultados foram analisados comparando os dados obtidos de camundongos cujas células epiteliais tímicas expressavam Dicer (FOXN1 WT) com camundongos cujas células não apresentavam Dicer (FOX1 HT e M).

A análise da citometria revelou que a houve alterações na porcentagem de linfócitos $\mathrm{TCD}^{+}$expressando determinados TCRs dos 15 tipos analisados em camundongo que não expressa dicer em relação ao selvagem. Uma vez que as porcentagens de alguns TCRs foram alteradas nos camundongos sem dicer em relação ao selvagem, pode-se dizer que houve um descontrole da seleção desses linfócitos no timo. Sabendo que a ausência de Dicer interfere diretamente na maturação e desenvolvimento de miRNAs, estes resultados mostram que os miRNAs são importantes para a seleção do linfócito T, para que a tolerância central possa agir de forma funcional resultando na apoptose de linfócitos $T$ autorreativos.

\section{Conclusões}

A deleção de Dicer nas TECs altera o repertório do TCR em células T CD4+ do baço, indicando a participação dos miRNAs no processo de seleção negativa. Nossos estudos estão em andamento para melhor entendimento sobre a quebra da tolerância central.

\section{Agradecimentos}

\section{FAPESP \#2015/10107}

1 Kyewski, B. \& Klein, L. A central role for central tolerance. Annu. Rev Immunol. 24, 571-606 (2006). 2 Chen, C. Z., Schaffert, S., Fragoso, R., \& Loh, C. (2013). Regulation of immune responses and tolerance: The micro RNA perspective. Immunological reviews, 25. 3(1), 112-128.3 Kanellopoulou, C., Muljo, S. A., Kung, A. L., Ganesan, S., Drapkin, R., Jenuwein, T., ... \& Rajewsky, K. (2005). Dicer-deficient mouse embryonic stem cells are defective in differentiation and centromeric silencing. Genes \& development, 19(4), 489-501. 